\title{
EXCURSION TO OXFORD.
}

\section{Whit-Monday, May 17th, and Following Day.}

Directors-Prof. Prestwian, M.A., F.R.S., F.G.S., \&c., and James Parker, Esq., M.A., F.G.S.

(Report by W. H. HUdLeston, Esq., M.A., F.G.S.)

The party were received by the Directors about noon, when Prof. Prestwich commenced a demonstration of the palæontological collection inl the Unirersity Museum, directing attention more especially to the fossils from the neighbourhood.

Amongst the Portland fossils are some very fine specimens of Ammonites pectinatus, a new species figured but not described by Phillips in the Geology of Oxford. In the Kimmeridge Clay of the neighbourhood Rhynchonella inconstans oceurs sparingly towards the base, and Exogyra virgula is tolerably common, but Ostrea deltoidea is reported to be scarce. A somewhat unexpected circumstance is the occurrence of Rynch. inconstans, in what appears to be a Corallian matrix from the neighbourhood of Marcham.

The Oxford Museum is especially rich in the remains of the vertebrates from the varions Oolitic beds of the neighbourhood, ranging from the small mammals of the Stonesfield Slate to the huge femur of the Cetiosaurus from Kirklington (the magnum bonum of Prof. Phillips).* The Professor alluded also to the recent discovery in the Kimmeridge Clay of Iguanodon Prestwichii, a new species of that peculiar genus of Dinosaurs, which had not previously been discovered in strata older than the Wealden.

After enjoying the hospitality of the Directors, the party proceeded eastwards in the direction of Shotover, under their guidance. Mr. Parker had provided for the use of the Members a very useful octaro tract, containing a map and sections of the strata south of Oxford, with explanatory text. The strata represented on the map in ascending order are-

"1. Oxford Clay, on which Oxford itself is situated.

"2. Lower Calcareous Grit, resting on the Oxford Clay, and followed by

"3. Coral Rag. This is in part covered by

"4. Kimmeridge Clay.

* Reports are given of previous Excursions in Proc. Geol. Assoc., Vol. ii., p. 243 ; and Vol. iv., p. 91. 
"5. The Portland Sands (including Portland Rock) follow on the Kimmeridge Clay, on ascending Shotover Hill, and appear to some extent further eastward.

"6. The Iron Sands, capping Shotover Hill (east of Oxford) and Cumnor Hill (west of Oxford); attributed by some to Wealden, by others to Lower Green Sand.

"To the south-east the Kimmeridge Clay is covered by the ordinary Cretaceous Beds. The sands here are referable to ordinary Lower Green Sands, and these are further on covered by

"7. The Gault in which a few fossils are found, but only in one or two places. The Upper Green Sand and the Chalk are beyond the bounds of the map; but from every part of the district (excepting in the valley of the Thames) the long Berkshire range of Chalk-hills is a prominent feature bounding the southern horizon (highest elevation, 893 feet).

"Much of the district is covered with gravels: the Low Level Gravel, chiefly in the valleys (on the brink of this gravel Oxford is built), and the High Level Gravels, on the top of one or two hills."

Four horizontal sections were given, as follows :-

"The first Horizontal Section starts from the turn to Marston, about one mile due east from centre of Oxford (Carfax.)

"The surface of the clay at this point is $\mathbf{1} 86$ feet above sea-level. Oxford is built on a bed of (Low Level) gravel; the highest point being at Carfax, viz., 216 feet above sea-level. Taking the St. Clement's level as that of the average of the clay, the gravel appears to attain a maximum thickness of 30 feet; and that is the usual depth of the wells in the higher parts of Oxford. The main Headington Road runs due east; but a lane turns off, in a southeasterly direction, towards Shotover, just at the junction of the Oxford Clay with the Calcareous Grit.

"The section mainly follows this road. A quarry can be seen of Coral Rag, resting on the sands of the Lower Calcareous Grit; and further up, of the Kimmeridge Clay, resting on the Coral Rag. Still further, the Portland Sands are seen, resting on the Kimmeridge Clay; and in the large pit on the left the Iron Sands to all appearance are seen capping the Portland.

"The Second Section, across Shotover-hill, and a considerable extension of high land eastward, is taken from the Geological Survey.

"It shows the outlying character of the Iron Sands, which for this 
reason have been associated with the ordinary Lower Green Sands, occurring some few miles to the south, and in direct relation with Gault, Upper Green Sand, and Chalk.

"The Third Section (also following the Survey) is one across the Cumnor Hill, drawn in the same direction. The lithological character of the sands is somewhat different; and it will be observed they rest directly on the Kimmeridge Clay. On Shotover they rest on the Portland Sands.

"The Fourth Section is one across a portion of the Coralline Oolite ridge, which divides the Thames Valley from that of the Ock. It does not rise to any great height.

"The height of the meadows on the bank of the Thames, in a line with the section, is 207 feet above sea-level; those on the bank of the Ock 192 feet. The highest point in this part of the ridge is on the main road, where the surface is 268 feet. The distance between the Thames and Ock at this point is a little over three miles, so that the rise of some 60 feet over so large an extent is scarcely perceptible. The section therefore exhibits the very level character of the beds."

The region traversed by the two first horizontal sections was visited on the afternoon of the first day; the third and fourth sections traverse the country visited on the second day.

The following is the vertical section in the direction of Shotover according to Mr. Parker, omitting the Lower Calcareous Grit and Oxford Clay.

Feet.

IroN SANDS, with geodic concretions of Ironstone. Laminæ of white and coloured clays. Freshwater Shells ... ... 60

Portuand Sands, with large spheroidal concretions and irre$\begin{array}{llllllll}\text { gular bands of Limestone } & \ldots & \ldots & \ldots & \ldots & \ldots & 60\end{array}$

Kimmeridge Clay-A bed of calcareons concretions near the $\begin{array}{llllllllll}\text { base } & \ldots & \ldots & \ldots & \ldots & \ldots & \ldots & \ldots & \ldots & 70\end{array}$

Coral RAG. The top bed in some places is Oolitic and worked for Freestone. Elsewhere "raggy" and "coralline" $\ldots \quad 30$

Since the last visit of the Association in 1874, the evidence as to the development of the Oxford Clay and underlying beds in the immediate vicinity of the City, has been carefully sifted by Prof. Prestwich, from data supplied by the boring for coal at Wytham, in 1829, and by a boring at St. Clement's for water a few years later. For reasons which it is difficult to understand, the late Prof. 
Phillips assigned to the Oxford Clay here the excessive thickness of $600 \mathrm{ft}$., but Prof. Prestwich has shown that its thickness at St. Clement's, according to his interpretation of the strata passed through in the bore-hole, is $263 \mathrm{ft}$., underlain by a considerable thickness of Bathonian beds, as might be expected from their great development in the Woodstock country. The saline character of the water obtained from the bore-hole at St. Clement's induces the suspicion that possibly the Trias was reached at the moderate depth of $420 \mathrm{ft}$. The clay-pits at St. Clement's are in the upper part of the Oxford Clay of this district, and many specimens of Ammonites vertebralis and Gryphas dilatata were noted.

Proceeding along Cowley Marsh, the party ascended the slope of the Lower Calcareous Grit sands, which may sometimes be seen resting directly on the Oxford Clay. On the top of the plateau (Bullingdon Green) are numerous Coral Rag pits. The vertical sections here seem barely to attain $26 \mathrm{ft}$. The highest beds of all consist of true Coral Rag, full of the prostrate branches of Thecomilia, and with tabular lines of Thamnastroea and Isastrcea. Mammilated urchins, as Cidaris florigemma, and Hemicidaris intermedia, are not uncommon. Opinions differ as to whether this rubbly rag represents a reef in situ or a drift accumulation. The late Prof. Phillips inclined towards the latter view. This Rag rests upon a hard crystalline limestone series, which, in this neighbourhood, is divided by a sort of soft oolitic grit and sand, but this division can barely be recognized at Headington. The limestone series rests upon the loose sand of the Lower Calcareous Grit. There is a profusion of fine shells in these hard limestones, a monomyarian fauna somewhat prevailing. Lima rigida, and $L$. laviuscula are common and conspicuous.

Northwards, at the old Windmill Pits, the Coral Rag may be observed under somewhat different conditions, and further up the hill the junction with the Kimmeridge Clay is seen, but the quarry is now disused, and this very interesting section is not so fresh in consequence. One specimen of Rhynch. inconstans was secured from the Clay, and higher up a few small bad specimens of $E x$. virgula. Remains of large Saurians are found from time to time. The Clay is succeeded by the Portland Beds, here consisting for the most part of sands and irregular limestone bands and concretions, in which were noted Trigonia gibbosa, Cardium dissimile, \&c., \&c.

The lateness of the hour precluded anything more than a basty 
glance at this part of the section. The Portland Beds are succeeded by the often Aiscussed Shotover Iron-Sands, usually grouped as Wealden. At this spot they are not rich in fossils, but towards Wheatley (about a mile to the south) beds of Unio, Cyrena, and Paludina are found.

Descending the hill, the Coral Rag was again inspected in the Headington quarries (see general section at Shotover supra). The following is a careful and detailed section of the Headington Quarries by Mr. Blake, :- -

ft. in.

1. False-bedded comminated Shell Limestone $\quad \ldots \quad 16 \quad 0$

2. Irregular Coral Rag with Thecosmilia passing into

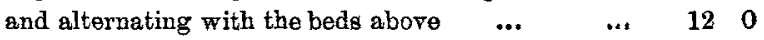

3. Semi-oolite Shell-bed with Cid. florigemma... $\quad \ldots \quad 7 \quad 0$

4. Pebbly bed and layers of nodules with $A m$. cordatus $\quad \begin{array}{lll}0 & 8\end{array}$

5. Sands of the Lower Calcareons Grit

In this section No. 2 represents the Coral Rag passing upwards into a building stone (such as has been much used at Oxford in former years); whilst it rests upon a hard-bedded semi-oolitic limestone, No. 3, full of large shells, as Ammonites plicatilis, Phasianella striata, Natica clytia, Astarte ovata, Gervillia aviculoides, Perna mytiloides, Corbicella lavis, Myoconcha Samanni, Lima laviuscula, Pecten lens, P. vimineus, and spines of Cidaris florigemma.

In the evening Mr. Parker exhibited a collection of the fossils of the neighbourhood, principally from the Oxford Clay, Lower Calcareous Grit, Coral Rag, and Kimmeridge Clay. A number of interesting diagrams were also exhibited and explained.

On the following day the party left in carriages for Cumnor, $3 \frac{1}{2}$ m. S.W., Fyfield, $7 \frac{1}{2}$ m. S.W., and Marcham, 7 m. S.S.W. of Oxford. Near the Cumnor Clump is a pit in the Kimmeridge Clay, where the specimen of Iguanodon, recently exhibited at the Geological Society, was found. These remains, according to Mr. Hulke, illustrate nearly every part of the skeleton of an immature individual, which however differs materially from the Wealden fossil. Prof. Seeley even believed that the differences were important enough to place the animal in a new genus.

The following section of the Iguanodon-pit was drawn up by

* Blake and Hudleston, “Corallian Rocks of England," Quart. Jonrn. Geol. Soc., for May, 1877, p. 309. 
Prof. Prestwich for the use of the party. Beneath a capping of Lower Greensand there comes-

$a$. Light-coloured and mottled Clay (altered).

$b$. Grey Clay with numerous small ferro-argillaceons concretions in the upper part-few fossils.

c. Layer of large flat Septaria.

d. Grey Clay, with seams of fossils, Ammonites, Thracia, \&c., Pliosaurus.

e. Ditto with Cardium, Trigonia, \&c., Vertebra of Icthyosaurus.

$f$. Thin ferruginous seam full of Gryphca vigula, a few Lingula, \&c.Iguanodon-bed.

From the top of the hill near the Clump, there is a most extensive prospect, bounded at the far south by the Chalk escarpment. The day being very clear, Mr. Parker was able to explain his views as to the configuration of the district.

Shortly after regaining the high road, the party entered the very remarkable stone-pit on Bradley farm. There is much variety here within a short compass. The highest series is a mass of Coral Rag, here containing, for the most part, a large Monomyarian fauna, but with bands of the typical urchins. At its base is a white flaggy and shelly limestone, of very slight thickness, but important as occupying a position analogous to that of the great Shell-bed in the Headington district. Beneath this come loose sandy masses in places even argillaceous, and then a massive limestone grit, the lower portion containing a profusion of Gasteropoda. This may be regaraed as a shell-bed towards the top of the Lower Calcareous Grit, and its contents are rather unusual. $A m$. vertebralis is common, $A$. perarmatus less so. There is an abundance of small Natice and one or two species of Nerita occur very similar to forms in the Bathonian beds, also a species of Amberlya, very similar to the Amberlya nodosa of the Great Oolite. It is, perhaps, the only place in England where Chemnitzia abbreviata has been found. To these we must add Cylindrites Lhuidii in great numbers, and several specimens of Cerithium and Nerinaea usually small. No lack of bivalves accompany these, but the assemblage of small and peculiar univalves is worthy of attention. The loose sands of the Lower Calcareous Grit underlie the bed.

The drive from Cumnor towards Fyfield presents no very marked geological features, but there are some interesting though rather obscure sections in the latter parish, where false bedding is seen on a very considerable scale. 
The whole party were most hospitably entertained by Mr. Parker at Fyfield Manor House. A portion of the party afterwards paid a hasty visit to one of the celebrated Marcham quarries, where the Corallian beds are thin and variable, and where the uppermost Limestone (Coral Rag) is often replaced by sandy beds with concretions. Below this group comes the main Shell-bed of this district, here charged with a very large variety of Trigonia perlata and other fossils. The lower beds of limestone contain many specimens of Natica, but the peculiar fauna of Bradley is no longer found. The bottom of this quarry is very full of water. The great quarry whence so many Lower Calcareous Grit fossils have been obtained, was not visited, as the evening was drawing on, and the Members were anxious to return to Oxford.

\section{EXCURSION TO AYLESBURY.}

(In conjunction with the Hertfordshire Natural History Society.)

MAY 29, 1880.

Director :-W. H. Hudleston, E\&Q., M.A., F.G.S.

(Report by The Director.)

On arriving at Aylesbury about noon, the first place visited was Mr. Hill's well-known brick-pit on the Bierton Road, where excavations have been going on for nearly a century, and where there is at present a very remarkable and instructive section, which has hardly attracted the notice that it deserves. The appearances in this section are singularly deceptive, and unless they were interpreted by the light of the recent drainage works are calculated to mislead the very elect themselves. The clay which is made into bricks is very sandy, and differs considerably from ordinary Kimmeridge Clay in the nature of its fossils, as does that at $\mathrm{Mr}$. Locke's pit, near Hartwell, which is on the same geological horizon. In Mr. Hill's pit this clay is observed to change colour very much on approaching the surface, and the uppermost four feet are somewhat more sandy, thus facilitating a change, which is due to atmospheric agencies, and which may be observed in the exposed parts of nearly all clays, though the effects vary according to 